\title{
Prevalence of male-killer in a sympatric population of two sibling ladybird species, Harmonia yedoensis and Harmonia axyridis (Coleoptera: Coccinellidae)
}

\author{
SUZUKI NORIYUKI ${ }^{1}$, YUICHI KAMEDA ${ }^{1}$ and NAOYA OSAWA ${ }^{2}$
}

\author{
${ }^{1}$ Laboratory of Conservation Biology, Center for Northeast Asian Studies, Tohoku University, 41 Kawauchi, Aoba, Sendai, Miyagi \\ 980-8576, Japan; e-mails: fvgnoriyuki@gmail.com; yuichi.c.kameda@gmail.com \\ ${ }^{2}$ Laboratory of Forest Ecology, Graduate School of Agriculture, Kyoto University, Kyoto, Japan; e-mail: osawa@kais.kyoto-u.ac.jp
}

Key words. Coleoptera, Coccinellidae, Harmonia axyridis, H. yedoensis, aphidophagous ladybird, early male-killing, maternal investment, maternally inherited bacteria, sex ratio, sibling cannibalism, sibling species

\begin{abstract}
In predatory ladybirds male embryos in clutches of eggs infected with male-killing bacterial endosymbionts do not hatch and are consumed by female hatchlings. Moreover, it is predicted that infection with male-killing bacteria should be prevalent in a ladybird population if the fitness advantage to female ladybirds due to the resulting reallocation of resources is high. We compared male-killer bacterial prevalence in two sibling species of the ladybird genus Harmonia that use different host ranges. Harmonia yedoensis feeds mostly on the highly elusive pine aphid and its hatchlings can greatly enhance their ability to capture prey and thus their survival by consuming un-hatched eggs in the clutch. In contrast, Harmonia axyridis feeds on a wide range of prey and consumption of un-hatched eggs by the hatchlings does not necessarily increase their foraging success. In the study area where these two species of ladybird occur sympatrically 14 of the 22 females of $H$. yedoensis (64\%) laid clutches of eggs of which approximately only a half hatched and did not produce male offspring, whereas only one of 12 of the females of $H$. axyridis (8\%) exhibited symptoms indicating infection with male-killing bacteria. In the $H$. yedoensis that exhibited symptoms of being infected with male-killing bacteria, the total allocation of resources to each hatchling, which was provided by laying larger eggs and eating the un-hatched eggs in the clutch, was considerable. These results suggest that the difference in the prevalence of infection with male-killing bacteria in these two species of ladybird may reflect differences in the quality of their prey and their foraging behaviour.
\end{abstract}

\section{INTRODUCTION}

Bacterial endosymbionts can enhance their own transmission efficiency by manipulating the reproductive mode of their arthropod hosts (O’Neill et al., 1997). An early male-killing strategy, in which endosymbiont bacteria kill their male hosts during embryogenesis, is reported in a range of insect hosts, including Coleoptera, Lepidoptera and Diptera (Hurst \& Jiggins, 2000). This strategy is beneficial to maternally inherited bacteria because the death of the male hosts confers a fitness advantage on the remaining female hosts due to the reallocation of resources from male embryos to female hatchlings (Hurst, 1991; Hurst et al., 1997). Moreover, fewer siblings reduce competition for resources within a patch (Jaenike et al., 2003; Martins et al., 2010). Furthermore, it is hypothesized that female offspring are less likely to suffer inbreeding depression because they have few, if any, brothers (Werren, 1987). In addition to the benefits resulting from the death of male embryos, bacterial infection can confer direct benefits to the female host, including resistance to pathogens or parasites (Unckless \& Jaenike, 2011). Theory predicts that male-killing bacteria should be prevalent in a host population if the fitness advantage for female hosts is high (Hurst et al., 1997; Jaenike, 2009). However, even though there is considerable variation in the prevalence of infection of different host species and populations (Hurst \& Jiggins, 2000; Jaenike, 2009), the relationship between male-killer prevalence and ecological factors affecting the fitness of infected hosts remains unclear.

Aphidophagous ladybirds are suitable models for studying male-killing bacteria, because many species harbour male-killing bacteria (e.g., Wolbachia, Rickettsia, or Spiroplasma) (Majerus \& Hurst, 1997; Majerus, 2006; Majerus \& Majerus, 2012). Most species of aphidophagous ladybirds lay eggs in tight clutches and their offspring forage on aphids. It can be difficult for the small hatchlings to capture aphids, owing to their larger body size, defensive behaviour and spatial-temporal variation in colony size. As a result, small ladybird hatchlings are at risk of starvation (Hurst \& Majerus, 1993; Majerus \& Hurst, 1997). In this context, female neonates can enhance their ability to capture and reduce their risk of starvation by consuming un-hatched male eggs. Therefore, infection with male-killing bacteria is likely to occur in aphidophagous species of ladybirds. In some species, moreover, it is reported that infected offspring develop faster and become larger and thereby increasing the potential fecundity of adult females, even without consuming un-hatched eggs (Elnagdy et al., 2013; but see Hurst et al., 1994). Despite these advantages, there is considerable variation in the prevalence of male-killing bacteria in different species and populations of ladybirds (Majerus et al., 1998; Hurst \& Jiggins, 2000; Weinert et al., 2007; Majerus \& Majerus, 2012). The prevalence of male-killing bacteria is theoretically sensitive to small differences in the selective advantage coupled with the rate of maternal transmission (Jaenike, 2009), however, the ecological mechanisms responsible for the variation in male-killer prevalence in ladybirds are still unclear.

In this study, we focused on two sympatrically distributed sibling species of ladybirds that use strikingly different ranges of prey. Harmonia yedoensis (Takizawa, 1917) (Coleoptera: Coccinellidae) is a specialist predator that occurs only on pine trees and feeds mostly on the giant pine aphid, Cinara pini (Linnaeus, 1758), which is both large and very mobile (Sasaji, 1998). Mothers of $H$. yedoensis invest a large amount of resource in their offspring, as its eggs are large and sibling egg cannibalism frequently occurs even in the absence of any bacterial infection, which enhances the ability of their offspring to hunt mobile prey (Osawa \& Ohashi, 2008; Noriyuki et al., 2011). It has been experimental- 
ly demonstrated that egg consumption immediately after hatching greatly enhances the searching ability and efficiency of $H$. yedoensis hatchlings in capturing C. pini, and their probability of moulting to the next instar (Noriyuki et al., 2011). In contrast, the sibling species Harmonia axyridis (Pallas, 1773) is a generalist predator that utilizes various species of prey in the field (Osawa, 2000). Even though $H$. axyridis produces smaller eggs than $H$. yedoensis and the intensity of sibling egg cannibalism within a clutch is low, $H$. axyridis hatchlings are able to capture their less mobile aphid prey (Noriyuki et al., 2011). Although sibling egg consumption can also enhance the survival of $H$. axyridis hatchlings, the fitness advantage is low, especially when aphid density is high (Osawa, 1992). Therefore, the reallocation of resources from un-hatched eggs to hatchlings is more advantageous for $H$. yedoensis than $H$. axyridis. Consequently, we hypothesized that the prevalence of infection with male-killer bacteria should be higher in $H$. yedoensis than $H$. axyridis. To test this hypothesis, we determined the percentage of eggs that hatched and the sex ratio of the offspring of these two sympatrically occurring sibling species of ladybirds. We also compared the investment in each offspring, which is closely correlated with hatchling performance in $H$. yedoensis, in infected and uninfected lines of this species. The results suggest that the variation in the prevalence of malekilling bacteria in these two species of ladybirds may reflect differences in the quality of their prey and foraging behaviour.

\section{MATERIAL AND METHODS}

\section{Ladybirds}

Twenty-five females of $H$. yedoensis and 12 of $H$. axyridis were collected at Iwakura, Kyoto $\left(135^{\circ} 79^{\prime} \mathrm{E}, 35^{\circ} 09^{\prime} \mathrm{N}\right)$, central Japan, in April and May 2011. All females were individually maintained in plastic Petri dishes ( $9 \mathrm{~cm}$ in diameter by $1.5 \mathrm{~cm}$ deep) at $25^{\circ} \mathrm{C}$ and under a $16 \mathrm{~L}: 8 \mathrm{D}$ photoperiod, and provided with a surplus of pea aphids, Acyrthosiphon pisum (Harris, 1776). Kept under these conditions the females produced many clutches of eggs. Each Petri dish was replaced by a new one every day in order to remove adult faeces, which contain odours that are thought might deter oviposition in ladybirds (Agarwala et al., 2003). Nevertheless, three females of $H$. yedoensis failed to produce offspring and were excluded from the analyses (Appendix). Egg clutches were kept under the same laboratory conditions as described above and the numbers of eggs and larvae that hatched from each clutch (up to 15 clutches per female) were counted and the percentage of eggs that hatched calculated. Hatchlings were fed with a mixture of powdered drone honeybee, dried yeast and sucrose, following Niijima et al. (2000). Subsequently, sex of the newly emerged adults was determined by examination of their abdominal morphology (males of both $H$. yedoensis and $H$. axyridis have an obvious notch in the posterior margin of the last abdominal sternite; Sasaji, 1977). In addition, 17 females of H. yedoensis and 6 of $H$. axyridis were chosen from those collected in the field and the length $(l)$ and width $(w)$ of 10 eggs laid by each of the females were measured under a microscope. Egg size was then estimated as $l w^{2} \pi / 6$ (Takakura, 2004). The total maternal investment per hatchling was estimated as the average egg size divided by the average proportion that hatched.

\section{Bacteria}

After making the measurements described above, some of the females were fed an antibiotic and its effect on the male-killing trait was assessed. Two of the original 25 females of $H$. yedoensis that previously produced only female progeny and two that produced offspring with a normal sex ratio were fed a $10 \%$ mixture of the antibiotic tetracycline hydrochloride in honey diluted with water plus $A$. pisum every day. There was no control treatment of

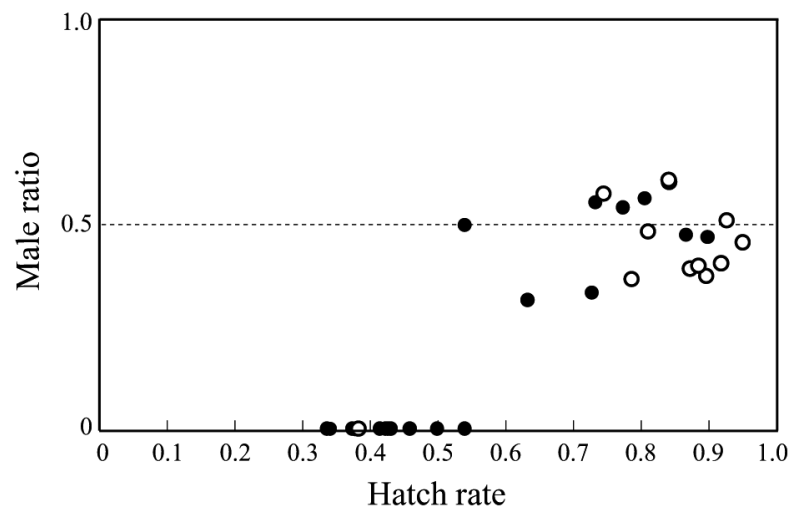

Fig. 1. Relationship between offspring sex ratio and the proportion of the eggs that hatched of those laid by females of Harmonia yedoensis (closed circles) and Harmonia axyridis (open circles). The dotted line shows the parity sex ratio.

females fed just honey diluted in water plus $A$. pisum because the sex ratio of ladybirds fed honey and aphids is not affected (e.g., Hurst et al., 1992; Majerus et al., 1998).

We performed a diagnostic polymerase chain reaction (PCR) analysis to confirm the presence of Spiroplasma bacteria, because detailed molecular studies have reported the presence of Spiroplasma spp. in male-killing lines of both $H$. yedoensis (Osawa et al., unpubl. data) and H. axyridis (Majerus et al., 1998). All specimens of ladybirds were preserved in $99 \%$ ethanol after making the measurements described above, and the whole abdomen of each specimen was homogenized and then digested with proteinase K. These samples were then analyzed for Spiroplasma by performing PCR using the primer pair MGSO (van Kuppeveld et al., 1992) and HaIn1 (Hurst et al., 1999) and the following reaction conditions: $2 \mathrm{~min}$ initial denaturation at $95^{\circ} \mathrm{C}$; followed by 35 cycles of $20 \mathrm{~s}$ denaturation at $95^{\circ} \mathrm{C}, 1 \mathrm{~min}$ annealing at $57^{\circ} \mathrm{C}$ and $30 \mathrm{~s}$ of extension at $72 \mathrm{C}$; then $10 \mathrm{~min}$ of final extension at $72^{\circ} \mathrm{C}$. A second PCR analysis was performed under the same conditions if the result of the first was negative. All PCR amplifications were performed with TaKaRa ExTaq DNA polymerase (Takara, Otsu, Japan) with an appropriate positive control (a sample of Spiroplasma sp.) and negative control (distilled water).

\section{Statistics}

The proportion of eggs that hatched was analyzed using a generalized linear mixed model with a binomial error structure (GLMM; Schall, 1991) and the lmer function of the lme4 library of the R software package (version 2.10.1, R Foundation for Statistical Computing, Vienna, Austria). The identities of the mothers were represented as random terms and repeated sampling was conducted of the same focal mothers (Schall, 1991). Egg size was also analyzed using a GLMM with a lmer function including a Gaussian error structure.

\section{RESULTS}

The $H$. yedoensis and $H$. axyridis used consisted of male-killing (MK) lines that produced only daughters and normal sex ratio (NSR) lines that produced offspring of both sexes. Here, each female and her offspring constituted a line. Fourteen of the 22 females of $H$. yedoensis $(63.64 \%)$ produced MK lines and the remaining eight females NSR lines, which produced nearly equal numbers of male and female offspring (Fig. 1, Appendix). With one exception $(53.91 \%)$ the percentage of eggs laid by the MK lines of $H$. yedoensis that hatched was less than $50 \%$ (mean $\pm \mathrm{SE}$ $=41.70 \pm 0.02 \%)$, and significantly lower than that of the NSR lines $\left(\right.$ mean $\pm \mathrm{SE}=74.42 \pm 0.04 \%$; GLMM: line, $\chi^{2}{ }_{1}=34.61, P$ 
TABLE 1. Proportion of eggs that hatched and sex ratios of the offspring of two females of Harmonia yedoensis from male killing (MK) lines and two from normal sex ratio (NSR) lines before and after treatment with the antibiotic tetracycline hydrochloride. Brood number indicates the maternal line used in each experiment.

\begin{tabular}{ccccccccccc}
\hline \multirow{2}{*}{$\begin{array}{c}\text { Brood } \\
\text { no. }\end{array}$} & $\begin{array}{c}\text { Sex ratio } \\
\text { group }\end{array}$ & \multicolumn{4}{c}{$\begin{array}{c}\text { No. of } \\
\text { clutches }\end{array}$} & $\begin{array}{c}\text { Proportion } \\
\text { that hatched }\end{array}$ & $\begin{array}{c}\text { No. of adult } \\
\text { progeny }\end{array}$ & Male:female & & \multicolumn{3}{c}{$\begin{array}{c}\text { No. of } \\
\text { clutches }\end{array}$} & & $\begin{array}{c}\text { Proportion } \\
\text { that hatched }\end{array}$ & $\begin{array}{c}\text { No. of adult } \\
\text { progeny }\end{array}$ \\
\hline 8 & MK & 15 & $0.376 \pm 0.038$ & 10 & 0.000 & & 7 & $0.674 \pm 0.086$ & 6 & 0.500 \\
11 & MK & 15 & $0.422 \pm 0.046$ & 9 & 0.000 & & 9 & $0.770 \pm 0.071$ & 2 & 0.500 \\
15 & NSR & 15 & $0.632 \pm 0.036$ & 19 & 0.316 & & 11 & $0.651 \pm 0.037$ & 23 & 0.435 \\
18 & NSR & 14 & $0.773 \pm 0.040$ & 35 & 0.543 & & 6 & $0.759 \pm 0.055$ & 10 & 0.400 \\
\hline
\end{tabular}

$<0.001)$. In contrast, only one of the 12 females of $H$. axyridis $(8.33 \%)$ laid egg clutches of which few hatched and produced only female offspring. The percentages of the eggs that hatched of the remaining 11 mothers were high and their offspring sex ratios were normal (Fig. 1, Appendix). Consequently, in the Iwakura ladybird population, the proportion of MK lines was significantly higher in $H$. yedoensis than $H$. axyridis (Fisher's exact test, $\chi^{2}{ }_{1}=$ 9.63, $P<0.01)$

After the tetracycline hydrochloride treatment, the percentage of eggs that hatched of MK line females of $H$. yedoensis significantly increased (GLMM: treatment, $\left.\chi^{2}=74.12, P<0.001\right)$ and they produced both male and female offspring (Table 1). In contrast, the antibiotic treatment did not affect the percentage of eggs that hatched of NSR line females $\left(\chi_{1}^{2}=0.01, P=0.92\right)$ or the sex ratio of their offspring $\left(\chi^{2}=0.12, P=0.72\right.$; Table 1). The results of the diagnostic PCR analysis were positive for all MK lines and negative for all NSR lines of both $H$. yedoensis and $H$. axyridis.

Average egg size of $H$. yedoensis was significantly greater (mean $\left.\pm \mathrm{SE}=0.300 \pm 0.002 \mathrm{~mm}^{3}\right)$ than that of $H$. axyridis $(0.230$ $\pm 0.002 \mathrm{~mm}^{3}$; linear mixed model: species, $F_{1,228}=22.799, P<$ $0.001)$. Moreover, the proportion of eggs that hatched was significantly lower in NSR lines of $H$. yedoensis than NSR lines of $H$. axyridis (GLMM: species, $\chi^{2}=7.19, P<0.01$ ). The total investment per offspring differed significantly between the MK lines of $H$. yedoensis, the NSR line of $H$. yedoensis and NSR lines of $H$. axyridis (one-way ANOVA with the Tukey-Kramer HSD test, $F_{2}$, ${ }_{20}=72.014, P<0.001$; Fig. 2).

\section{DISCUSSION}

In the study area, the prevalence of male-killer, based on low percentage of eggs that hatched and female-biased sex ratios, was significantly higher in $H$. yedoensis than $H$. axyridis. Moreover, antibiotic treatment and diagnostic PCR results indicate that bacterial endosymbionts belonging to Spiroplasma spp. were responsible for killing the male embryos. In fact, more than half of the females of $H$. yedoensis examined exhibited appropriate symptoms and were infected with Spiroplasma, whereas only one female of $H$. axyridis did. In nature, $H$. yedoensis mostly feeds on the giant pine aphid, which is a highly elusive prey for the hatchlings, perhaps because negative mating interactions with $H$. axyridis restrict the food choice of $H$. yedoensis (Noriyuki et al., 2012). In this situation, sibling egg consumption greatly enhances the efficiency of the hatchlings of $H$. yedoensis in capturing the giant pine aphid and so reduces its risk of starvation (Noriyuki et al., 2011). Thus, our results support the hypothesis that infection with male-killing bacteria is likely to be more prevalent in species that gain a fitness advantage through altered resource reallocation within a clutch.

The level of allocation of resources by females to their daughters could be an important determinant of the prevalence of male-killer in ladybirds. Osawa \& Ohashi (2008) report that the eggs of $H$. yedoensis are larger than those of $H$. axyridis and we found that the percentage of eggs that hatched was significantly lower in NSR lines of H. yedoensis than of H. axyridis (Fig. 1). Therefore, $H$. yedoensis laid a larger number of eggs that do not hatch than $H$. axyridis independent of whether they are infected with male-killer or not, but the physiological basis for this is unknown. Nevertheless, male-killing bacteria can further increase the resource allocation to each hatchling. In fact, more resources were allocated to each offspring in MK lines of $H$. yedoensis than in NSR lines of either $H$. yedoensis or H. axyridis (Fig. 2). Therefore, male-killing bacteria may confer fitness advantages to $H$. yedoensis via resource reallocation and consequently favours the high transmission of the bacteria. This may account for the higher prevalence of male-killing bacteria in the sample of $H$. yedoensis collected than is reported for most other species of ladybird (Hurst \& Jiggins, 2000; Majerus, 2006; Majerus \& Majerus, 2012).

At present, it is unclear whether the incidence of male-killer infection in the population studied has reached equilibrium or is a transient epidemic. In this study, we examined the two species of ladybird occurring at just one site, thus it is difficult to fully evaluate the ecological and evolutionary factors that affect the prevalence of infection with male-killing bacteria. To resolve this problem further studies of the variations in the prevalence of male-killing bacteria in more populations of these two species and over longer periods of time are needed. The reported prevalence of male-killing bacteria is low in most areas where $H$. axyridis populations occur in Japan (Matsuka et al., 1975; Nakamura et al., 2005), although there are a few exceptions (Majerus et al., 1998). This indicates that widespread infection with malekilling bacteria is hampered in some way in these populations.

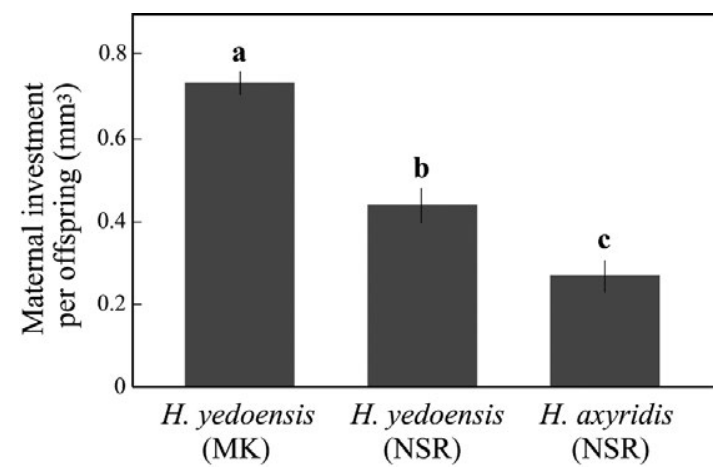

Fig. 2. The maternal investment per hatchling in terms of volume in the male killing (MK) lines of Harmonia yedoensis and normal sex ratio (NSR) lines of both H. yedoensis and Harmonia axyridis (mean $\pm \mathrm{SE}$ ). The volumes for each mother are based on their average egg sizes and proportion of the eggs that hatched. Different letters indicate a significant difference among categories (ANOVA with the Tukey-Kramer HSD test, $P<0.05$ ). The single NSR line of $H$. axyridis was not included in the analysis (see text for details). 
In addition to biogeographical surveys, phylogenetic patterns in the polymorphism of both the host and parasite genomes can be used to estimate the evolutionary history of the infection (e.g., Jiggins, 2003; Dyer \& Jaenike, 2004; Graham \& Wilson, 2012). Thus phylogenetic techniques could be used to determine the persistence of the interaction between male-killing Spiroplasma and Harmonia ladybirds on an evolutionary time scale.

Alternatively, factors other than the benefits that accrue from the reallocation of resources to hatchlings might also contribute to the prevalence of male-killing bacteria in Harmonia ladybirds. We speculate that avoidance of inbreeding depression (cf. Werren, 1987) may not be a very important factor in the prevalence of infection with male-killing bacteria in $H$. yedoensis, because it takes the adults at least a few weeks to reach sexual maturity after emergence (Okada et al., 1978) and in that time period they are likely to disperse from the areas where they developed (Sasaji 1998). However, it is possible that reduction in the competition for resources among sibling larvae enhances the likelihood of infection with male-killing bacteria. Moreover, male-killing bacteria may confer direct benefits on the host by enhancing host development and resistance to disease, as various pathogens and parasites infect ladybirds, especially $H$. axyridis (reviewed in Kenis et al., 2008; Roy et al., 2011; Ceryngier \& Twardowska, 2013). Therefore, the relative importance of these factors, which are not mutually exclusive, must be evaluated. Nevertheless, our study supports the inference that the differences in the foraging behaviour of ladybird hatchlings, which reflect the marked differences in the prey of these sympatrically distributed sibling species, can at least in part account for the inter-specific variation in the prevalence of male-killing bacteria.

ACKNOWLEDGEMENTS. We thank J. Jaenike and K.-I. Takakura for comments on the manuscript, A.F.G. Dixon for correcting the English, T. Nishida and S. Chiba for helpful discussion, H. Okanishi and T. Kobayashi for assistance with the experiments and T. Hosokawa for providing a positive control sample for the PCR experiment. This study was supported by a Research Fellowship for Young Scientists to S. Noriyuki and a Grant-inAid for Scientific Research (No. 20405047 \& 24255013) to N. Osawa from the Japan Society for the Promotion of Science.

\section{REFERENCES}

Agarwala B.K., Yasuda H. \& KaJITA Y. 2003: Effect of conspecific and heterospecific feces on foraging and oviposition of two predatory ladybirds: role of fecal cues in predator avoidance. - J. Chem. Ecol. 29: 357-376.

Ceryngier P. \& Twardowska K. 2013: Harmonia axyridis (Coleoptera: Coccinellidae) as a host of the parasitic fungus Hesperomyces virescens (Ascomycota: Laboulbeniales, Laboulbeniaceae): A case report and short review. - Eur. J. Entomol. 110: $549-557$.

DYER K.A. \& JAENIKE J. 2004: Evolutionary stable infection by a male-killing endosymbiont in Drosophila innubila: molecular evidence from the host and parasite genomes. - Genetics $\mathbf{1 6 8}$ : 1443-1455.

Elnagdy S., Majerus M.E.N., Gardener M. \& Lawson Handley L.-J. 2013: The direct effects of male killer infection on fitness of ladybird hosts (Coleoptera: Coccinellidae). - J. Evol. Biol. 26: $1816-1825$.

Graham R.I. \& Wilson K. 2012: Male-killing Wolbachia and mitochondrial selective sweep in a migratory African insect. BMC Evol. Biol. 12: 204.

HurST L.D. 1991: The incidences and evolution of cytoplasmic male killers. - Proc. R. Soc. (B) 244: 91-99.
Hurst G.D.D. \& JigGins F.M. 2000: Male-killing bacteria in insects: mechanism, incidence, and implications. - Emerg. Infect. Dis. 6: 329-336.

HuRst G.D.D. \& MaJerus M.E.N. 1993: Why do maternally inherited microorganisms kill males? - Heredity 71: 81-95.

Hurst G.D.D., Majerus M.E.N. \& Walker L.E. 1992: Cytoplasmic male killing elements in Adalia bipunctata (Linnaeus) (Coleoptera: Coccinellidae). - Heredity 69: 84-91.

Hurst G.D.D., Purvis E.L., Sloggett J.J. \& Majerus M.E.N. 1994: The effect of infection with male-killing Rockettsia on the demography of female Adalia bipunctata L. (two spot ladybird). - Heredity 73: 309-316.

Hurst G.D.D., Hurst L.D. \& Majerus M.E.N. 1997: Cytoplasmic sex-ratio distorters. In O’Neill S.L., Hoffmann A.A. \& Werren J.H. (eds): Influential Passengers: Inherited Microorganisms and Arthropod Reproduction. Oxford University Press, Oxford, pp. 125-154.

Hurst G.D.D., von der Schulenburg J.H.G., Majerus T.M.O., Bertrand D., Zakharov I.A., Baungaard J., Völkl W., STOUTHAMER R. \& Majerus M.E.N. 1999: Invasion of one insect species, Adalia bipunctata, by two different male-killing bacteria. - Insect Mol. Biol. 8: 133-139.

JAENIKE J. 2009: Coupled population dynamics of endosymbionts within and between hosts. - Oikos 118: 353-362.

JaeniKe J., Dyer K.A. \& Reed L.K. 2003: Within-population structure of competition and the dynamics of male-killing Wolbachia. - Evol. Ecol. Res. 5: 1023-1036.

JiGGINS F.M. 2003: Male-killing Wolbachia and mitochondrial DNA: selective sweeps, hybrid introgression and parasite population dynamics. - Genetics 164: 5-12.

Kenis M., Roy H.E., Zindel R. \& Majerus M.E.N. 2008: Current and potential management strategies against Harmonia axyridis. - BioControl 53: 235-252.

MAJERUS M.E.N. 2006: The impact of male-killing bacteria on the evolution of aphidophagous coccinellids. - Eur. J. Entomol. 103: $1-7$.

Majerus M.E.N. \& Hurst G.D.D. 1997: Ladybirds as a model system for the study of male-killing symbionts. - Entomophaga 42: 13-20.

Majerus T.M.O. \& Majerus M.E.N. 2012: Male-killing in the Coccinellidae: testing the predictions. - Evol. Ecol. 26: 207225.

Majerus T.M.O., Majerus M.E.N., Knowles B., Wheeler J., BertRand D., Kuznetzov V.N., Ueno H. \& Hurst G.D.D. 1998: Extreme variation in the prevalence of inherited male-killing microorganisms between three populations of Harmonia axyridis (Coleoptera: Coccinellidae). - Heredity 81: 683-691.

Martins A.B., Ventura I.M. \& KlaczKo L.B. 2010: Spiroplasma infection in Drosophila melanogaster: What is the advantage of killing males? - J. Invertebr. Pathol. 105: 145-150.

MatsuKa M., Hashi H. \& OKada I. 1975: Abnormal sex-ratio found in the lady beetle, Harmonia axyridis Pallas. - Appl. Entomol. Zool. 10: 84-89.

Nakamura K., Ueno H. \& Miura K. 2005: Prevalence of inherited male-killing microorganisms in Japanese population of ladybird beetle Harmonia axyridis (Coleoptera: Coccinellidae). — Ann. Entomol. Soc. Am. 98: 96-99.

NijJima K., Tobita M. \& Matsuka M. 2000: Development of lowcost and laborsaving technique for group rearing of a ladybird, Harmonia axyridis. - Tamagawa Univ. Res. Rev. 6: 23-33 [in Japanese, English abstr.].

Noriyuki S., OsaWA N. \& Nishida T. 2011: Prey capture performance in hatchlings of two sibling Harmonia ladybird species in relation to maternal investment through sibling cannibalism. -Ecol. Entomol. 36: 282-289. 
Noriyuki S., OsaWa N. \& Nishida T. 2012: Asymmetric reproductive interference between specialist and generalist predatory ladybirds. - J. Anim. Ecol. 81: 1077-1085.

Okada I., NiJima K. \& Toriumi Y. 1978: Comparative studies on sibling species of lady beetles, Harmonia yedoensis and H. axyridis (Coleoptera: Coccinellidae). - Bull. Fac. Agric. Tamagawa Univ. 18: 60-68 [in Japanese, English abstr.].

O'Neill S.L., Hoffmann A.A. \& Werren J.H. 1997: Influential Passengers: Inherited Microorganisms and Arthropod Reproduction. Oxford University Press, Oxford, $214 \mathrm{pp}$.

Osawa N. 1992: Sibling cannibalism in the ladybird beetle Harmonia axyridis Pallas: fitness consequences for mothers and offspring. - Res. Popul. Ecol. 34: 45-55.

OsaWa N. 2000: Population field studies on the aphidophagous ladybird beetle Harmonia axyridis (Coleoptera: Coccinellidae): resource tracking and population characteristics. - Popul. Ecol. 42: 115-127.

Osawa N. \& OHASH K. 2008: Sympatric coexistence of sibling species Harmonia yedoensis and H. axyridis (Coleoptera: Coccinellidae) and the roles of maternal investment through egg and sibling cannibalism. - Eur. J. Entomol. 105: 445-454.

Roy H.E., Rhule E., Harding S., Lawson Handley L.-J., Poland R.L., Riddick E.W. \& Steenberg T. 2011: Living with the enemy: parasites and pathogens of the ladybird Harmonia axyridis. - BioControl 56: 663-679.

SASAJI H. 1977: How to distinguish the sexes in ladybirds. - Insectarium 14: 13 [in Japanese].
SASAJI H. 1998: Natural History of the Ladybirds. University of Tokyo Press, Tokyo, 251 pp. [in Japanese].

SCHALL R. 1991: Estimation in generalized linear models with random effects. - Biometrika 78: 719-727.

TAKAKURA K. 2004: Variation in egg size within and among generations of the bean weevil, Bruchidius dorsalis (Coleoptera, Bruchidae): effects of host plant quality and paternal nutritional investment. - Ann. Entomol. Soc. Am. 97: 346-352.

UNCKLESS R.L. \& JAENIKE J. 2011: Maintenance of a male-killing Wolbachia in Drosophila innubila by male-killing dependent and male-killing independent mechanisms. - Evolution 66: 678-689.

van Kuppeveld F.J., van der Logt J.T., Angulo A.F., van Zoest M.J., Quint W.G., Niesters H.G., Galama J.M. \& Melchers W.J. 1992: Genus- and species-specific identification of mycoplasmas by $16 \mathrm{~S}$ rRNA amplification. - Appl. Environ. Microbiol. 58: 2606-2615.

Weinert L.A., Tinsley M.C., Temperley M. \& Jiggins F.M. 2007: Are we underestimating the diversity and incidence of insect bacterial symbionts? A case study in ladybird beetles. - Biol. Lett. 3: 678-671.

WERREN J.H. 1987: The coevolution of autosomal and cytoplasmic sex-ratio factors. - J. Theor. Biol. 124: 317-334.

Received November 5, 2013; revised and accepted January 2, 2014 Prepublished online March 14, 2014

ApPENDIX. Proportion of eggs that hatched and sex ratios of the offspring of 25 Harmonia yedoensis females and 12 Harmonia axyridis females collected at Iwakura, Kyoto, central Japan. MK - male killing line; NSR - normal sex ratio line; N/A - not available.

\begin{tabular}{|c|c|c|c|c|c|c|c|c|}
\hline $\begin{array}{c}\text { Brood } \\
\text { no. }\end{array}$ & Species & $\begin{array}{l}\text { No. of } \\
\text { clutches }\end{array}$ & $\begin{array}{c}\text { Proportioin that } \\
\text { hatched (mean } \pm \text { SE) }\end{array}$ & $\begin{array}{c}\text { No. of adult } \\
\text { progeny }\end{array}$ & $\begin{array}{l}\text { Male } \\
\text { ratio }\end{array}$ & $\begin{array}{l}\text { Sex ratio } \\
\text { line }\end{array}$ & $\begin{array}{c}\text { Egg size } \\
\left(\mathrm{mm}^{3}, \text { mean } \pm \mathrm{SE}\right)\end{array}$ & $\begin{array}{c}\text { Total investment per } \\
\text { offspring }\left(\mathrm{mm}^{3}\right)\end{array}$ \\
\hline 1 & H. yedoensis & 15 & $0.430 \pm 0.026$ & 16 & 0.000 & MK & $0.282 \pm 0.003$ & 0.656 \\
\hline 2 & H. yedoensis & 15 & $0.458 \pm 0.111$ & 10 & 0.000 & MK & $0.314 \pm 0.003$ & 0.686 \\
\hline 3 & H. yedoensis & 15 & $0.539 \pm 0.049$ & 8 & 0.000 & MK & $0.310 \pm 0.006$ & 0.575 \\
\hline 4 & H. yedoensis & 15 & $0.373 \pm 0.027$ & 15 & 0.000 & MK & $0.280 \pm 0.009$ & 0.751 \\
\hline 5 & H. yedoensis & 15 & $0.335 \pm 0.040$ & 6 & 0.000 & MK & $0.246 \pm 0.005$ & 0.734 \\
\hline 6 & H. yedoensis & 14 & $0.338 \pm 0.030$ & 9 & 0.000 & MK & $0.275 \pm 0.004$ & 0.814 \\
\hline 7 & H. yedoensis & 15 & $0.373 \pm 0.028$ & 11 & 0.000 & MK & $0.294 \pm 0.004$ & 0.790 \\
\hline 8 & H. yedoensis & 15 & $0.376 \pm 0.038$ & 10 & 0.000 & MK & $0.353 \pm 0.007$ & 0.938 \\
\hline 9 & H. yedoensis & 15 & $0.498 \pm 0.046$ & 11 & 0.000 & MK & $\mathrm{N} / \mathrm{A}$ & \\
\hline 10 & H. yedoensis & 15 & $0.425 \pm 0.052$ & 18 & 0.000 & MK & N/A & \\
\hline 11 & H. yedoensis & 15 & $0.422 \pm 0.046$ & 9 & 0.000 & MK & $0.326 \pm 0.004$ & 0.772 \\
\hline 12 & H. yedoensis & 14 & $0.413 \pm 0.027$ & 11 & 0.000 & MK & $0.270 \pm 0.003$ & 0.654 \\
\hline 13 & H. yedoensis & 7 & $0.429 \pm 0.079$ & 7 & 0.000 & MK & $0.287 \pm 0.005$ & 0.670 \\
\hline 14 & H. yedoensis & 14 & $0.429 \pm 0.034$ & 30 & 0.000 & MK & $0.315 \pm 0.005$ & 0.733 \\
\hline 15 & H. yedoensis & 15 & $0.632 \pm 0.036$ & 19 & 0.316 & NSR & $0.329 \pm 0.004$ & 0.520 \\
\hline 16 & H. yedoensis & 15 & $0.727 \pm 0.036$ & 9 & 0.333 & NSR & $0.325 \pm 0.004$ & 0.447 \\
\hline 17 & H. yedoensis & 14 & $0.867 \pm 0.026$ & 21 & 0.476 & NSR & N/A & \\
\hline 18 & H. yedoensis & 14 & $0.773 \pm 0.040$ & 35 & 0.543 & NSR & N/A & \\
\hline 19 & H. yedoensis & 14 & $0.898 \pm 0.027$ & 17 & 0.471 & NSR & $0.306 \pm 0.003$ & 0.341 \\
\hline 20 & H. yedoensis & 15 & $0.805 \pm 0.056$ & 23 & 0.565 & NSR & $0.311 \pm 0.004$ & 0.387 \\
\hline 21 & H. yedoensis & 15 & $0.732 \pm 0.035$ & 9 & 0.556 & NSR & N/A & \\
\hline 22 & H. yedoensis & 15 & $0.539 \pm 0.068$ & 14 & 0.500 & NSR & $0.278 \pm 0.005$ & 0.517 \\
\hline 23 & H. yedoensis & 13 & $0.150 \pm 0.042$ & 3 & N/A & & N/A & \\
\hline 24 & H. yedoensis & 9 & $0.247 \pm 0.082$ & 3 & $\mathrm{~N} / \mathrm{A}$ & & N/A & \\
\hline 25 & H. yedoensis & 2 & $0.106 \pm 0.075$ & 0 & N/A & & N/A & \\
\hline 26 & H. axyridis & 9 & $0.382 \pm 0.041$ & 17 & 0.000 & MK & N/A & \\
\hline 27 & H. axyridis & 7 & $0.744 \pm 0.057$ & 26 & 0.577 & NSR & $0.246 \pm 0.005$ & 0.331 \\
\hline 28 & H. axyridis & 7 & $0.918 \pm 0.029$ & 32 & 0.406 & NSR & $0.229 \pm 0.002$ & 0.249 \\
\hline 29 & H. axyridis & 6 & $0.786 \pm 0.051$ & 30 & 0.367 & NSR & N/A & \\
\hline 30 & H. axyridis & 7 & $0.872 \pm 0.058$ & 28 & 0.393 & NSR & N/A & \\
\hline 31 & H. axyridis & 8 & $0.841 \pm 0.058$ & 33 & 0.606 & NSR & $0.249 \pm 0.003$ & 0.296 \\
\hline 32 & H. axyridis & 7 & $0.841 \pm 0.058$ & 18 & 0.611 & NSR & N/A & \\
\hline 33 & H. axyridis & 3 & $0.896 \pm 0.032$ & 8 & 0.375 & NSR & N/A & \\
\hline 34 & H. axyridis & 7 & $0.950 \pm 0.013$ & 35 & 0.457 & NSR & $0.232 \pm 0.003$ & 0.244 \\
\hline 35 & H. axyridis & 8 & $0.885 \pm 0.047$ & 25 & 0.400 & NSR & $0.219 \pm 0.004$ & 0.248 \\
\hline 36 & H. axyridis & 5 & $0.926 \pm 0.020$ & 45 & 0.511 & NSR & N/A & \\
\hline 37 & H. axyridis & 6 & $0.810 \pm 0.023$ & 31 & 0.484 & NSR & $0.204 \pm 0.003$ & 0.252 \\
\hline
\end{tabular}

*Broods 23, 24, and 25 were not included in the analyses because of the small number of adult progeny. 